\title{
The Effectiveness of 6M Implementation at Artebo MSME
}

\author{
Sitti Hardiyanti Arhas ${ }^{1}$, Suprianto ${ }^{2}$ \\ ${ }^{1}$ Universitas Negeri Makassar, ${ }^{2}$ Universitas Borneo Tarakan \\ E-mail: hardiyantiarhas@unm.ac.id
}

\begin{abstract}
Management is a tool to achieve the desired goals, with good management it will facilitate the realization of the goals of a company or organization. The effective and efficient use of elements in management owned by a business will be able to bring advantages to businesses and consumers. The management elements consist of Material, Method, Man, Machine, Money, and Market, known as 6M. This study aims to determine the effectiveness of the implementation of $6 \mathrm{M}$ at Artebo MSMEs. The research method used is a type of qualitative research, namely research in the form of words, sentences, schemes, and descriptions. The data sources consist of primary data and secondary data obtained from observations and interviews. Primary data comes from information, statements, and information from informants. Secondary data comes from documentation review. The main instrument in this study is the researcher himself with the aid of a mobile recorder; observation sheet; and interview sheets. The data collection techniques used were observation, interview, and documentation. The collected data is checked by triangulation, namely checking the validity of the data using something other than the data concerned for checking purposes or as a comparison. The data analysis technique used an interactive analysis model. The stages in data analysis taken in this study include data reduction; presentation of data; validation test; and verification. As for the results of the study, namely MSME Artebo has implemented the elements of $6 \mathrm{M}$ management effectively, this is adjusted to the conditions of the micro-business being run. The man that is owned is one person, namely the owner. Money used in production activities can be explored because the material is easy to use and affordable. The materials used mostly comes from nature, namely wood. The machine used is a simple machine because of the limited resources that can be utilized. The method used is a traditional method. And the market that is used to sell products is done in a Word of Mouth manner.
\end{abstract}

Keywords: Effectiveness, implementation, 6M, MSMEs

\section{INTRODUCTION}

The role of MSME in the Indonesian Economy plays a role as driving economic dynamics with a role that can reduce unemployment, alleviate poverty, provide foreign exchange for the State (Habiburahman, Alam, Dunan, \& Haninun, 2019), increase development (Singh, Rathi, \& Garza-Reyes, 2020), and investment (Das \& Das, 2012), reduce unemployment.

There are four factors that cause MSMEs to have a strategic position in Indonesia. First, MSMEs do not require large capital compared to large businesses so that starting a business is not as difficult as large businesses. Second, the labor required does not require higher education. Third, most businesses are home-based businesses so they don't need to pay more for office rentals. Fourth, MSMEs are proven to have strong resilience when Indonesia is hit by an economic crisis. SMEs face difficulties in adapting their strategies to changing markets, and in 


\section{Jurnal Administrare: Jurnal Pemikiran Ilmiah dan Pendidikan Administrasi Perkantoran Volume 6 Number 2 July- December 2019. Pages 250-256}

competing with large firms (Vasanth, Kishore, \& Majumdar, 2012). Also, it is caused by a lack of understanding of MSME actors regarding management.

Management is a tool to achieve the desired goals (Taylor, 2017). According to Follet, the art of getting/getting things done by empowering people. With good management, it will facilitate the realization of the goals of a company (Mclarney \& Rhyno, 1999). The effective and efficient use of elements in management owned by a business will be able to bring advantages to businesses and consumers. The management elements consist of Material, Method, Man, Machine, Money, and Market which is known as 6M (Boca, 2015; Limbasiya, 2015; Melani, Santjaka, \& Latif, 2018). Maximum use of management elements is required by all institutions/organizations (Barat, 2009; Collett, 1989; Drucker, 2012; Kotler, 2000), including by MSMEs, because if these management elements cannot be utilized optimally, the achievement of goals will be more difficult to realize.

Artebo is a MSMEs that was founded in 2005. Artebo is the only traditional musical instrument business in Bone Regency that sells lutes, drums, flutes, and pui-pui. Not only making musical instruments for the Bugis tribe, Artebo also made other traditional musical instruments such as lute. The price offered is more affordable compared to traditional musical instruments in Makassar City. In addition, manufacturing materials are easy to obtain. But more than a decade after this effort started, there is no significant increase in sales due to the sales strategy. marketing is only done on the basis of the Word of Mouth (WoM). This means that marketing is only done by word of mouth. Even though the sale was once carried out outside Sulawesi, the sale was due to information from the buyer's close relative. So, there are often no sales in a month. Moreover, Artebo MSMEs do not have employees due to limited funds they have.

\section{METHOD}

This type of research is qualitative. Qualitative research is research in the form of words, sentences, schemes, and descriptions (Sugiyono, 2017). Sources of data consist of primary data and secondary data obtained from observations and interviews. Primary data comes from information, statements, and information from informants. Secondary data comes from documentation review. The main instrument in this study is the researcher himself with the aid of a mobile recorder; observation sheet; and interview sheets.

The data collection techniques used were observation, interview, and documentation. The collected data is checked by triangulation, namely checking the validity of the data by using something other than the data concerned for checking purposes or as a comparison. The data analysis technique uses an interactive analysis model from (Huberman \& Miles, 1994). The stages in data analysis taken in this study include data reduction; presentation of data; validation test; and verification.

\section{RESULT AND DISCUSSION}

Management decisions are only a means of achieving the desired goals. With good management, it will facilitate the realization of the goals of a company. There are management 
elements that are important to consider in advancing a business. Based on the research results, the $6 \mathrm{M}$ in research is in accordance with the opinion (Terry \& Franklin, 1972) this is described as follows:

\section{Man}

Man in management, the human factor is the most decisive. Humans who make goals and humans also carry out the process to achieve goals. Without humans, there would be no work process, because basically humans are working creatures. Therefore, management arises because of the people working together to achieve goals. Man: refers to human resources owned by the organization.

Based on the results of research conducted, MSME Artebo does not have permanent employees, this business is only run by the owner, Mr. Arifuddin. This happened because this business started from trial and error, namely because of his love for traditional musical instruments so that he had the desire to make traditional musical instruments. After making a traditional musical instrument, unexpectedly when playing it, someone wants to buy the lute. After a few days, the first buyer wanted to also buy a typical Bugis flute. So it began to appear to open an Artebo business.

MSME Artebo does not have employees because orders do not come every day. However, Artebo MSME sometimes gets a lot of orders. So it requires a lot of energy, but the energy used is from the family itself, namely from his wife, children, and nephews. However, if the order is only 1 to 2 pieces, Mr. Arifuddn as the owner does it alone.

\section{Money}

Money is an important support in a business. Money is a medium of exchange and a measure of value. The size of the results of activities can be measured from the amount of money circulating in the company. Therefore money is an important tool to achieve goals because everything must be calculated rationally. This will relate to how much money must be provided to pay for labor salaries, the tools needed and must be purchased, and how many results will be achieved from an organization. Mismanagement of money will cause the destruction of a business.

Based on the research results, the money needed to make a musical instrument is not expensive starting from Rp. 30,000-Rp. 200,000 depending on the type of musical instrument produced. The lowest use of funds is the flute instrument, while the most expensive is the drum. As for the price offered, the flute is sold at IDR 45,000-IDR 60,000, the price is based on the number of items purchased. The lute is pegged at a price of Rp. 900,000. The drum is pegged at a price of Rp. 750,000 - Rp. 1,800,000 depending on the size desired. The Gambus is sold for Rp. 1,300,000.

\section{Materials}

Materials consist of semi-finished materials (raw material) and finished materials. In the business world to achieve better results, apart from humans who are experts in their fields, they must also be able to use materials as a means. Because matter and humans cannot be separated, without matter the desired results will not be achieved.

The materials used in Artebo MSMEs are materials related to the manufacture of musical instruments such as wood, small bamboo measuring 2-3 cm (bulo), cowhide or goatskin, nylon, dyes (phlox and paint), binders, punching tools, sandpaper, snarers, chisels, and other carpentry tools. 


\section{Jurnal Administrare: Jurnal Pemikiran Ilmiah dan Pendidikan Administrasi Perkantoran Volume 6 Number 2 July- December 2019. Pages 250-256}

Based on the results of the interview, the materials available are materials that are easy to obtain except bamboo for flutes because the bamboo used is a special bamboo, the tone of bamboo bulo is different from the tone of ordinary bamboo and more durable than an ordinary bamboo.

\section{Machines}

Machines in company activities, machines are needed. The use of machines will bring convenience or generate greater profits and create work efficiency. In technological advances, humans are no longer as machine assistants as in the past before the Industrial Revolution occurred. In fact, on the contrary, machines have changed their position to become human helpers.

Based on the results of the research conducted, the machines used are simple machines, namely electric wood shavings to smooth wood in making lutes. However, the drum hole carving does not use a machine. The owner has a large punching machine but it is not used because in use it causes high vibration, so that after use it often causes excruciating pain to the user. So, to make a hole in a drum, a manual carving process is carried out.

\section{Method}

The method is a good working procedure that will make the work run smoothly. A method can be expressed as determining how the work of a task will be carried out by giving various considerations to the target, the facilities available, and the use of time, as well as money and business activities. It should be remembered that although the method is good, while the person who implements it does not understand or have no experience, the results will not be satisfactory. Thus, the main role in management remains a human being.

The method used in making traditional musical instruments is the conventional/traditional method, this is done because of limited funds. So that the work on each traditional musical instrument is carried out without the help of reliable machines. This is not too burdensome for Artebo MSMEs because buyers do not come every day so when they have free time, the owner chisels the existing wood bit by bit to be used as drums. For the manufacture of the flute, the actors prepared a lot of stock compared to the others because it did not require a lot of time.

\section{Market}

A market is a place where the organization disseminates (markets) its products. Marketing the product is of course very important because if the goods produced do not sell, the process of producing goods will stop. It means that the work will not proceed. Therefore, market rulers in the sense of distributing production results are a determining factor in the company. In order for the market to be controlled, the market and prices of goods must be in accordance with the tastes of consumers and the purchasing power (abilities) of consumers.

The market for this product for sale is the place of business of the MSME owner. Marketing is done conventionally, namely the Word of Mouth (WoM). Sometimes other buyers inform prospective buyers to buy products at MSME Artebo, Marketing has not been done online on the available online platforms due to the owner's limited knowledge of the existing online platforms. 


\section{DISCUSSION}

\section{Man}

Based on the results of research conducted, MSME Artebo does not have permanent employees, this business is only run by the owner, Mr. Arifuddin. This is because the number of orders is not large. In fact, Human Resources can be applied to increase production capacity, the volume of manufactured products, and quality of production (Blaga, 2020). The success of an organization is determined by the quality of the people in it. HR will work optimally if organizations can support their career advancement by seeing what their competencies are. Usually, competency-based HR development will increase employee productivity so that the quality of work is higher as well and leads to customer satisfaction and the organization will benefit. Human Resources can be defined as all people involved in an organization to strive for the realization of predetermined organizational goals.

\section{Money}

The limited funds owned is one of the inhibiting factors why intellectual organizations develop. Although development is the desired outcome for new ventures because of the many advantages of its large size, most new businesses find it difficult to grow, because of their limited finances. However, Artebo MSME expenditures are also not too large so that the cash can still be used to always produce products according to community demand.

To carry out its activities, management requires costs, both for the purchase and maintenance of equipment, purchase of raw materials/materials, payment of labor salaries, and so on. Good money management will affect the success or failure of management that is carried out. Therefore, money management must be carried out rationally in order to achieve the stated objectives.

\section{Materials}

The materials used in the Artebo MSMEs are materials related to the making of musical instruments. Material management in all organizational activities aims to provide goods or services to customers. The efficiency of managing existing materials can have a major impact on customer satisfaction and cost reduction (Lourenço \& Ravetti, 2018). Proper material management of one component can increase the productivity and cost-efficiency of a product and help ensure its timely completion, which in turn improves the performance of an organization.

\section{Machines}

Based on the research results, the machines used are simple machines. One of the supporting factors in the implementation of the production process is the use of machines. With the use of machines, the production volume or productivity will increase, so that the company is able to obtain large profits. 


\section{Jurnal Administrare: Jurnal Pemikiran Ilmiah dan Pendidikan Administrasi Perkantoran Volume 6 Number 2 July- December 2019. Pages 250-256}

The machine is a means of production that has a very important role in the productivity of an organization or company, where productivity is highly dependent on machines and equipment.

According to (Assauri, 2016) There are two types of machines, namely generalpurpose machines, which are machines that are made to do certain jobs for various types of goods/products or parts of the product. Second, special purpose machines are machines that are planned and made to carry out one or several types of the same activities.

\section{Method}

The method used in making traditional musical instruments is the conventional/traditional method, this is done because of limited funds. Methos aims to streamline all types of existing activities. This means that activities are successful and effective, humans are faced with various alternative methods of how to carry out the work so that the way they do it can become a means or management tool to achieve goals. To carry out activities efficiently and effectively, humans are exposed to various alternative methods or ways of doing work. Therefore, the method or method is also considered as a means or management tool to achieve goals. For example, there are currently known various teaching methods or methods such as various lectures, case methods, incident methods, games, role-playing, and so on. The various methods, of course, differ in effectiveness and efficiency to achieve certain educational goals (Wijaya \& Rifa'i, 2016).

\section{Market}

Marketing is carried out by MSME Artebo, namely conventionally, namely the Word of Mouth (WoM). Currently, the market has a very important role in the business world. A company needs to do distribution, and this is very important for the development of the community's economy because it is tasked with delivering goods and services that are needed by consumers. After the goods are manufactured and ready to be marketed, the next stage in the marketing process is to determine the methods and rules that will be used to distribute the goods to the market. The distribution channel of an item is a channel used by producers to distribute these goods from producers to consumers. Marketing activities do not start at the completion of the production process, nor do they end when the sale is made. the organization must be able to provide satisfaction to consumers if it expects its business to continue so that the organization can be considered superior by consumers.

\section{CONCLUSION}

Based on the results of the research conducted, it can be seen that Artebo MSMEs have carried out the elements of $6 \mathrm{M}$ management effectively, this is adjusted to the conditions of the micro-business being run. The man that is owned is one person, namely the owner. Money used 
in production activities can be explored because the material is easy to use and affordable. The matherial used mostly comes from nature, namely wood. The machine used is a simple machine because of the limited resources that can be utilized. The method used is a traditional method. And the market that is used to sell products is done in a Word of Mouth manner.

\section{REFERENCES}

Assauri. (2016). Jenis-Jenis Invetory. Jenis-Jenis Invetory.

Barat, S. (2009). Global Marketing Management. Journal of Global Marketing. https://doi.org/10.1080/08911760903022556

Blaga, P. (2020). The Importance of Human Resources in the Continuous Improvement of the Production Quality. Procedia Manufacturing, 46, 287-293. https://doi.org/https://doi.org/10.1016/j.promfg.2020.03.042

Boca, G. D. (2015). 6M in Management Education. Procedia - Social and Behavioral Sciences. https://doi.org/10.1016/j.sbspro.2015.04.727

Collett, H. M. (1989). Management basics. Hospital Aviation. https://doi.org/10.1016/s07408315(89)80136-6

Das, S., \& Das, K. K. (2012). Factors Influencing the Information Technology Adoption of Micro, Small and Medium Enterprises ( MSME ): An Empirical Study. International Journal of Engineering Research and Application.

Drucker, P. (2012). Management. In Management. https://doi.org/10.4324/9780080939063

Habiburahman, Alam, I. A., Dunan, H., \& Haninun. (2019). MSMEs empowerment and development strategy model. Journal of Advanced Research in Dynamical and Control Systems. https://doi.org/10.5373/JARDCS/V11I12/20193209

Huberman, A. M., \& Miles, M. B. (1994). Data Management and Analysis Methods. In Handbook of Qualitative Research.

Kotler, P. (2000). Marketing Management, Millenium Edition. Marketing Management. https://doi.org/10.1016/0024-6301(90)90145-T

Limbasiya, N. (2015). The Views on Happiness: A Dialectic Approach. Vision: The Journal of Business Perspective. https://doi.org/10.1177/0972262915610976

Lourenço, H. R., \& Ravetti, M. G. (2018). Supply chain management. In Handbook of Heuristics. https://doi.org/10.1007/978-3-319-07124-4_54

Mclarney, C., \& Rhyno, S. (1999). Mary Parker Follett: Visionary leadership and strategic management. Women in Management Review. https://doi.org/10.1108/09649429910291131

Melani, F., Santjaka, A., \& Latif, R. V. N. (2018). SWOT Analysis on JKN Implementation in Ngaliyan Health Center Semarang in 2016. Unnes Journal of Public Health. https://doi.org/10.15294/ujph.v7i1.19197

Singh, M., Rathi, R., \& Garza-Reyes, J. A. (2020). Analysis and prioritization of Lean Six Sigma enablers with environmental facets using best worst method: A case of Indian MSMEs. Journal of Cleaner Production, 279, 123592. https://doi.org/https://doi.org/10.1016/j.jclepro.2020.123592

Sugiyono. (2017). Pendekatan Kuantitatif, Kualitatif, Kombinasi, R\&D dan Penelitian Evaluasi. Bandung: Alfa Beta. 
256 Jurnal Administrare: Jurnal Pemikiran Ilmiah dan Pendidikan Administrasi Perkantoran Volume 6 Number 2 July- December 2019. Pages 250-256

Taylor, F. W. (2017). The Principles of Scientific Management. In Modern Economic Classics-Evaluations Through Time. https://doi.org/10.4324/9781315270548-22

Terry, G. R., \& Franklin, S. G. (1972). Principles of management. RD Irwin Homewood, IL.

Vasanth, K., Kishore, M., \& Majumdar, K. (2012). INNOVATIVE MARKETING STRATEGIES FOR MICRO, SMALL \& MEDIUM ENTERPRISES. Interdisciplinary Journal of Contemporary Research in Business.

Wijaya, C., \& Rifa'i, M. (2016). Dasar-dasar manajemen: mengoptimalkan pengelolaan organisasi secara efektif dan efisien. Perdana. 